\title{
IAMJ
}

INTERNATIONAL

AYURVEDIC

MEDICAL JOURNAL

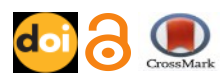

Research Article

ISSN: 23205091

Impact Factor: 5.344

\section{SUTIKASRAVA (LOCHIA) IN AYURVEDA - AN OBSERVATIONAL STUDY}

\section{Divya Pawar ${ }^{1}$, Sameer Gholap ${ }^{2}$}

${ }^{1}$ Post Graduate Scholar, ${ }^{2}$ Associate Professor and Guide,

Department of Prasuti Tantra Avum Striroga, SMBT College and Hospital, Nandi Hills, Dhamangaon, Igatpuri Nashik, Maharashtra, India

Email: divi.pawar94@gmail.com

https://doi.org/10.46607/iamj0807022020

(Published online: July 2020)

Open Access

(C) International Ayurvedic Medical Journal, India 2020

Article Received: 08/06/2020 - Peer Reviewed: 21/06/2020 - Accepted for Publication: 01/07/2020

Check for updates

\begin{abstract}
Ayurveda gives importance to the care of mother and her baby at every phase of her life under antenatal care and post-natal care. A post-natal period comes just after the expulsion of placenta up to 6 weeks thus defined as Puerperium and duration called as Puerperium period. Lochia is a vaginal discharge for the first fortnight during puerperium. The discharge originates from the uterine body, cervix and vagina. It is a cleansing discharge which stays for ten or twelve days after delivery in common practice. Lochia is of 3 types Lochia Rubra, Lochia Serosa and Lochia Aba. In Ayurveda the term Sutika can be used only after the expulsion of placenta. Sutika is more prone to diseases due to aggravation of Doshas. Also, she is more prone to infections which is called as Lochial Infection. A 45 patient's observational data collected from Ayurveda College for the study.
\end{abstract}

Keywords: Sutika, Sutika Kala, Sutika Srava, Lochia etc.

\section{INTRODUCTION}

In Ayurveda the term Sutika can be used only after the expulsion of placenta ${ }^{[1]}$ Kashyapacharya has said until and unless Aparapatana takes place stree should not be considered as Sutika. This clearly indicates that Aparapatan (expulsion of placenta) is also very important and it is also the part of delivery process. Lochia is the term given to the one-month period for women who go through after having a baby. It is mainly caused by the placenta coming away from the wall of your womb along with blood from any cuts or tears endured during 
labour. It may contain Cramps, mini contractions especially on breast feeding which helps uterus to contract back to its normal size. Immediately after birth it is heavy and may lead to more maternity pads but later on decreases and lasts for 6 weeks. It is quite normal, and the blood may have musty smell similar to that of menstrual bleeding. Lochia actually consists of Discharge and blood from the area on the uterine wall lining to which placenta was attached during pregnancy ${ }^{[1]}$.

1) The sloughed off endometrium which gets considerably thickened during pregnancy.

2) Blood and Mucus from the healing cervix.

3) Dead and necrotic tissue.

The blood in the Lochia comes mainly from the large raw area left on the inner uterus wall after the placenta detaches from it. While bleeding from this area controlled by contractions of the uterine muscles immediately after delivery thus it takes 2 weeks to heal. That's why bleeding is maximum in the first $2-3$ days after the birth then decreases over next two weeks.

\section{Aim and Objectives -}

- To understand Sutikasrava (Lochia) in both Ayurvedic and Allopathic Perspectives.

- To observe 45 patients having Sutika Srava (Lochia) in Sutikakala (puerperal period).

Material and Method- Reviewing Sutika Srava (Lochia) in Sutikakala (puerperal period) Ayurvedic classics, commentaries also recently published books and Research journals and modern science literature, the collection done and attempt to get co-relation between Ayurveda and Modern literature. An observation study done on 45 patients from Ayurveda College.

\section{According to Ayurveda -}

Sutika ${ }^{[2]}$ :-

Sutayaschapi Tatra Syadapara Chenna Nirgata | Prasutaapi Na Suta Stree Bhavatyevam Gate Sati II (Ka.S.11/6)

Kashyapacharya has said until and unless Aparapatana takes place Stree should not be considered as Sutika. This clearly indicates that Aparapatan (expulsion of placenta) is also very important and it is also the part of delivery process.

Evam cha masadadhyardhanmuktaharadiyantrana | Gatasutabhidhana syata punaravartavadarshanat \| (Va.sha.1/100)

Prasuta sardhamasante dristhve va punartave | Sutikanamahina syaditi dhanvantarermatam \| (Yo.ra.pa.6/10-2)

Sutika as per Ayurvedic literature references of Ashtanga Hridaya and Yogaratnakar is she that should be considered for one and half month (45days) from the time of Apatarpana ${ }^{[3][4]}$.

Sutikakala - The phase of regaining lost strength and attaining pre pregnant state of woman is called as Sutika Kala. It is stated by different Acharyas like,

Table 1:

\begin{tabular}{|c|c|}
\hline Texts & Duration \\
\hline $\begin{array}{l}\text { Sushruta }{ }^{[5]} \text { Ashtanga Hridaya }{ }^{[6]} \text { Ashtanga Sangraha }{ }^{[7]} \\
\text { Bhavaprakasha }{ }^{[8]}\end{array}$ & $1 \frac{1}{2}$ month \\
\hline Charaka ${ }^{[9]}$ & $5-7$ days \\
\hline Kashyapa ${ }^{[10]}$ & 6 months \\
\hline Yogratnakara $^{[11]}$ & 1 month \\
\hline Modern Science & $6-8$ weeks \\
\hline
\end{tabular}

Sutika Srava - A cleansing discharge is called as lochia for ten or twelve days after delivery in common practice.

Synonyms

1) Prasavashonitasrava

2) Yonisrava
Sutika Srava (Lochia) after delivery is denoted as good quality of Sutikasharirakriya (Puerperium Anatomy and Physiology).

Suterdhva te ye stravam ninditan shamayet budhan | Tasya asyamavarmpayamupayachet devataha \| (Ka.S.) 
Acharya Kashyapa has despicable and unhealthy. Because it contains Kleda, Apara shesha (Placental membranes) which once expelled out denotes Garbhashaya Shodhana (Cleaning of Uterus) ${ }^{[12]}$ Along with Sutika Srava (Lochia) normally vaginal bleeding stays for 3 4 days. Vaginal bleeding is different in every female. Generally, it gets reduced after $3^{\text {rd }}$ day. Prano hi shonitam anuvartate | But if vaginal bleeding persists even after that denotes Vipannavastha (Unhealthy). Vaginal bleeding is mentioned in Rasatarangini and given its treatment as well.

\section{Garbhashayam Prasutaya Savyatham}

Sthanvichyutam | Sankochatayatyashu Tatha Raktasravam Runadhhi Cha | Yonishcha Shithilabhuta Ssvasthanastu Prapadyate | (Rasatarangani)

\section{Sutika Srava Gandha (Odour) -}

The odour of lochia varies from patient to patient day by day. Normally the odour is not offensive and is described like old meat or strong like perspiration. Severe offensive or more or less quantity is not good in Sutika. Lactating mothers shows less lochia secretion than nonlactating mothers due to natural uterus size reoccurrence. In lochia infection offensive odour is found more along with pain in abdomen by increasing reddish lochia. Douglas and Rhees has done research on lochia and found $21.6 \%$ Sterile and $56.3 \%$ nonsterile bacteria in it ${ }^{[13]}$.

\section{According to Modern Science -}

Normal Puerperium ${ }^{[14]}$ - Puerperium is defined following childbirth during which the body tissues, especially the pelvic organs revert back approximately to the pre-pregnant state both anatomically and physiologically.

Abnormal Puerperium - Any deviation from the definition of normal Puerperium like Pyrexia, PPH, Lowback pain, perineal pain, bowel problems, mastitis, psychological problems, thromboembolism, postnatal anaemia etc called as Abnormal Puerperium.

Lochia- Modern science have considered Sutika Srava and vaginal bleeding as 'Lochia'. Which is divided in 3 factors like Composition, Colour and Quantity

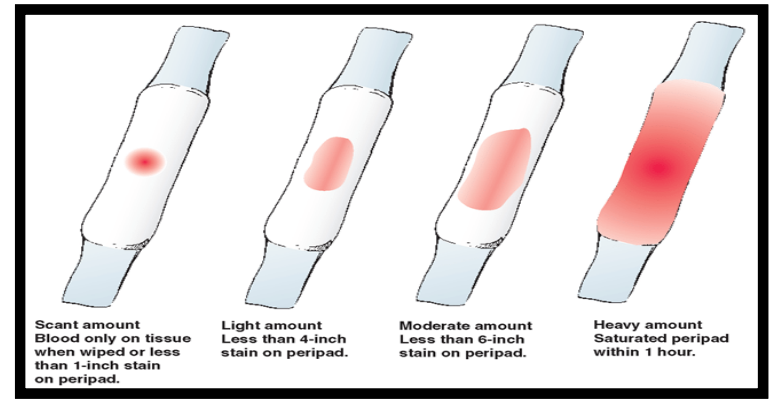

A) Lochia Rubra or Lochia Cruenta -

It is the first stage of bleeding and occurs in the first 4 days after birth. The lochia is distinctly bright red in colour and begins a day or two after the birth. It is mainly composed of blood, small bits of membranes, sheds of decidua, fragments of chorion, amniotic fluid, vernix caseosa, cervical discharge and any meconium.

B) Lochia Serosa or Lochia Sanguinolenta - It is a second stage of bleeding. The lochia is pale brown in colour. It lasts for 4 to 9 days. It contains wound exudation, red and white blood corpuscles, mucous from cervix and vagina. It contains less blood and more serum and hence it is pale brown in colour. It becomes more watery in consistency.

C) Lochia Alba or Lochia Purulenta- It is a final stage of lochia for about 10 to 15 days and it's much less heavy with a yellowish white creamy in colour. It lasts from around the third week to the sixth weak after birth. It contains decidual cells, fewer red blood cells which are made up of white blood cells, tissue cells, cholesterol, fat and mucus. It contains cervical mucus, debris from healing process in the uterus and vagina, organisms and markedly increased WBC's. The lochia is sterile for the first $2-3$ days but then becomes colonised by the bacteria going off a typical lochia smell which is normal not be confused with the bad odour from lochia in postpartum infection. The quantity of lochia may be scanty after a premature delivery but more than normal after a twin pregnancy or other conditions where uterus becomes more than the average size during pregnancy.

Lochia Infection Symptoms- Lochia or postpartum infections can occur between on and ten days after giving birth through vaginal tract. They are,

1. Fever, 2. Haemorrhages, 3. Abdominal pain 
Patients who undergone caesarean sections may have less lochia after 24 hours than who had vaginal deliveries.

\section{Management Of Lochia -}

1) Lochia doesn't need any specific management.

2) Use tampons or sanitary pads to prevent from bacterial infection.

3) Intercourse should be avoided to prevent from spreading of bacteria.

4) Regular bath with anti-infective agents.

5) Sitz bath should be followed.

\section{Abnormalities of Lochia -}

1) Secondary Postpartum Haemorrhage.

2) Pain in Abdomen. Lochia that remains red and abundant for longer than usual may indicate delayed involution of the uterus which may be because of retention of a piece of placenta within the uterus with infection,

1) Excessive dilatation of the uterus.

2) Complications during the delivery

3) Injury of the uterus during the delivery

4) Blood clotting disorder (Coagulopathy)

5) Hypotonia of the uterus - the most common cause of the uterine bleeding after childbirth characterized by its low contractive activity ${ }^{[15]}$.

If placental tissue is retained the uterus remains enlarged and this may show on an ultrasound scan. Lochia with offensive odour may indicate infection. It is possible for red lochial discharge to still be present at $6-$ 8 weeks. It is more commonly found after Instrumental Vaginal Delivery ${ }^{[16]}$.

\section{OBSERVATION}

1) 45 Patient's data collected from SMBT Ayurveda College.

2) Among them 14 (8 Primi + 6 Multipara) were undergone Caesarean section.

3) 28 (18 Primi + 10 Multipara) delivered by Full term vaginal delivery.

4) 3 (2 Primi + 1 Multipara) delivered from Instrumental Vaginal Delivery.

5) Criteria set according to duration like,

Mild $=0-3$ days

Moderate $=4-6$ days

Severe $=\geq 7$ days
Patients led $2-3$ sanitary pads per day every $6-8$ hours.

6) Results came with:

Mild $=14$ LSCS +2 Instrumental Vaginal Delivery = 16 patients

Moderate $=20$ FTND +1 Instrumental Vaginal Delivery $=21$ patients

Severe $=8 \mathrm{FTND}=8$ patients.

\section{DISCUSSION}

Sutika Srava is generally found after the delivery which is quite natural but if lasts for longer so that may be considered as secondary postpartum haemorrhage. From the above observation discussion can be drawn as During delivery 3 Avarta (Uterus, Cervix and Vagina) are included Thus Sutika Srava found more in those patients who undergone normal vaginal because baby comes out from these 3 ways thus complete opening takes place and let clots and blood pass through vagina in the form of lochia also doshas comes out and lasts for more than seven days. During Caesarean section (USCS or LSCS) Laparotomy is done and baby is taken out. As Prasava means delivery by Yoni (Vaginal canal) and to take baby out. Whereas in Caesarean section $1^{\text {st }} A$ varta (Uterus) is involved but not $2^{\text {nd }}$ and $3^{\text {rd }} A$ varta (Cervix and Vagina) thus blood clots and huge blood is cleaned by surgeon as a result it doesn't lead lochia for more than 3 days in quantity too. During Instrumental Vaginal Delivery it is performed through vagina only but due Sangha (Obstructed pathophysiology) it can't be processed easily but if performed ideally and well then lochia duration and quantity is same as Vaginal delivery. Personal hygiene should be followed to prevent from the puerperal infection. Thus, Acharyas have explained Sutika Paricharya to prevent from aggravated Doshas. As it is observational study it can be conducted over more patients too.

\section{CONCLUSION}

Sutika needs proper care and management with specific diet. Sutika Kala i.e. Lochia is a vaginal discharge for the first fortnight during puerperium. It is cleansing discharge which is at first bright red then white and yellowish in colour at last. Lochia contains blood clots, 
bits of membranes, blood corpuscles, mucus etc. which is highly prone for the infection. In the present study women who undergone full term normal delivery (FTND) has more day's lochia than Caesarean section and Instrumental vaginal delivery due to the involvement of 3 Artava which are completely involved in full term normal delivery (FTND) also somewhat in Instrumental vaginal delivery due to obstruction. In caesarean section baby is taken out abdominally and only $1^{\text {st }}$ Avarta has been cleansed during procedure thus lochia is found for less days. As it is an observational study it can be conducted over more patients in future.

\section{REFERENCES}

1. Murkoff, Heidi; Eisenberg, Arlene; Hathaway, Sandee (2002). What To Expect When You're Expecting (3rd Ed.). New York: Workman. P. 383. ISBN 0-7611-21323.

2. Pandit Hemraja, Vriddha Jivaka, Kasyapa Samhita Or Vriddhajivakiya Tantra, Vyotini Hindi Commentary, By Shree Satyapala Bhisagacharya, Kheelasthana, Sutikopakramaniya Adhyaya, 11/6, Chaukhamba Sanskrit Sansthan, Varanasi, 2010:305

3. Vagbhata Krita Ashtang Hridaya, Sarth Vagbhat, Garbhavakranti Adhyay, 1/100, Edited By Dr.Ganesh Krushna Garde, Rajesh Prakashan, Pune, 2012:128.

4. Yogratnakara, Vidyodini Hindi Tikakoshatam, Uttarardha, Sutikarogadhikara, 6/10-2, 7th Ed, Edited By Vaidya Shree Laxmipati Shashri, Bhishagratna Shree Bramhashankar Shashri, Chaukhamba Sanskrita Sansthan Varanasi, 2002:428

5. Sushruta, Sushruta, Samhita. English Translation And Commentary By P.V. Sharma, 1st Ed., Chaukhambha Viswabaharati, Varanasi Sharira Sthana, 1999, 10:16.

6. Acharya Vagbhata. Ashtanga Hridaya Of Translated By A Board Of Scholars, Introduction By _ Vaidya Asharam Sri Satguru Publications A Division Of Indian Books Centre Delhi, India, First Edition, Sarira Sthana, 1999, 11:100.

7. Acharya Vagbhata. Ashtanga Samgraha With Indu Commentary Edited By A. D. Pune, 1980, 3:41.

8. Acharya Bhavamishra, Bhavaprakash. Vidyotini Hindi Commentary By Bhishagratna Pt Sri Brahma Sankar Mishra, Chaukhambha Sanskrit Samsthan Purvakhand, 1975, 4:5.
9. Cakrapanidatta, Caraka Samhita. Vidyotini Hindi Commentary By Pt Kasha Nath Sharma And Dr. G N.Chaturvedi, Chaukhambha Sanskrit Samsthan Sarirta Sthana, 1975, 8:48.

10. Acharya Vridha. Jeevaka Reducted By Latter Descent Vatsya,Kasyapa Samhita Chaukhambha Visvbharati Varanasi Khaila Sthana. 1996; 11:52-53.

11. Sartha Yogaratnakar, Datto Ballala Borkar, Translator, Vol 2nd, Sutika Roga Chikitsa, Chap- 44, Shri Gajanana Book Depo Prakashana, Pune, 1984; P.639.

12. Pandit Hemraja, Vriddha Jivaka, Kasyapa Samhita Or Vriddhajivakiya Tantra, Vyotini Hindi Commentary, By Shree Satyapala Bhisagacharya, Sharira Sthana, Jatisutriya Adhyaya, Chaukhamba Sanskrit Sansthan, Varanasi, 2010:79

13. R.Gordon Douglas, Henrietta S. Rhees, Bacteriologic Findings In The Uterus During Labor And The Early Puerperium.1934 FEBRUARY 01;27(2):203-214 https://doi.org/10.1016/s0002-9378(34)90964-9

14. D C Dutta. $14^{\text {th }}$ Chapter Normal Puerperium. In: Hiralal Konar. Textbook of Obstetrics, 8th Ed. New Delhi: Jaypee Publications; Enlarged And Revised, 2015 Pp 168

15. Maria Shevisova. Postpartum Bleeding - The Healing Wound, April 4, 2016

http://www.tcmwell.com/tcmdiseases/internalmedicine/key-points-for-diagnosis-of-lochiorrhea.html

16. Suzannae Yates. Pregnancy And Childbirth. A Holistic Approach To Massage And Bodywork. Western Approach To The Postpartum. 2010, Pages 99-120 https://doi.org/10.1016/b978-0-7020-3055-0.00003-0

\section{Source of Support: Nil \\ Conflict of Interest: None Declared}

How to cite this URL: Divya Pawar \& Sameer Gholap: Sutikasrava (Lochia) In Ayurveda - An Observational Study. International Ayurvedic Medical Journal \{online\} 2020 \{cited July, 2020\} Available from: http://www.iamj.in/posts/images/upload/3831 3835.pdf 